doi: $10.1515 /$ scp-2016-0004

\title{
MOTIVATIONAL FACTORS IN THE ACQUISITION OF WELSH IN POLAND
}

\author{
KAROLINA ROSIAK AND MichaEL HORNSBY
}

Adam Mickiewicz University in Poznań

\begin{abstract}
For some years now, Welsh has been taught as a foreign language outside Wales, most especially in other Celtic countries, central Europe - and Poland. The first courses were established in the Catholic University of Lublin in the 1980s, and this provision has expanded over the years to include a Celtic language specialisation within the Faculty of English at Adam Mickiewicz University in Poznań. Relying at first on teachers from Wales to provide instruction in Welsh, the Centre for Celtic Studies is increasingly producing new, competent speakers/users of Welsh among the Poles. An obvious question to be asked concerns motivational issues - why, on the eastern edges of the European Union, are there people willing to put the effort into learning a language from the far west of Europe, when they have, in some cases, little contact with regular users of Welsh? Through the use of focus group interviews, the present study attempts to discover what motivates Polish students to study Welsh in a context of limited direct contact with the speakers of the language and limited, indirect access to Welsh language and culture.
\end{abstract}

Keywords: motivation, new speakers, language learning, Welsh, Poland, Celtic Studies

\section{Introduction}

Within the past decade or so, there has been increased movements of population between Poland and the United Kingdom, and Wales has seen an important number of Polish speakers establish themselves there as either temporary or as permanent residents. This has important implications for the learning and use of the Welsh language among some of Wales' newest residents, especially for the school-age population and for parental choice of school. What needs to be kept in mind, though, is that a very small but ideologically significant number of 
Polish speakers are acquiring Welsh in Poland as part of university programmes of Celtic Studies. This article presents an initial investigation into the learning and the use of Welsh outside of Wales in a context which has not been explored in any depth hitherto and represents an important contribution to the study of the acquisition of the Welsh language, which outside of Patagonia (and of course Wales), is not largely researched nor considered.

\section{History of Celtic Studies in Poland}

The history of research on selected aspects of Celtic Studies in Poland goes back to the beginning of the twentieth century when Stefan Czarnowski (18791937) published a number of journal articles, book chapters and books on Celtic literatures, mythology and religion. Over the course of the century, a number of distinguished scholars, such as Jerzy Kuryłowicz (Lviv University, Wrocław University, the Jagiellonian University in Kraków), Leszek Bednarczuk (the Jagiellonian University in Kraków), Alfred and Elżbieta Majewicz (Adam Mickiewicz University in Poznań) and Witold Stefański (University of Toruń) worked and published on aspects of Celtic Studies such as historical and comparative studies of the languages, phonology (Old Irish), the Italo-Celtic hypothesis and Celtic literary heritage. The majority of those publications were on the Celtic languages and linguistics, whereas literary, cultural and historical studies enjoyed less (academic) popularity (Stalmaszczyk 2006: 45-47). The first Chair of Celtic Philology was established in 1989 by the late Prof. Edmund Gussmann at the Catholic University of Lublin. However, Celtic Studies courses had been offered at the University as part of English Philology studies for a number of years before the Chair of Celtic Philology was formally established. Currently, there are two universities in Poland which offer full-time Celtic Studies courses, namely the Catholic University of Lublin and Adam Mickiewicz University in Poznań.

\section{Celtic Studies in Poznań}

The Department of Celtic Languages and Literatures at the School of English (now Faculty of English), Adam Mickiewicz University in Poznań was established in 2004. A number of modules on languages and literatures of the Celtic countries as well as an intensive Irish language course were offered to students of the School of English before the first full B.A. programme combining English Philology and Celtic Studies (i.e. the Celtic specialisation) was launched in the academic year 2007/2008 with 17 students. Three years 
later in the academic year 2010/2011 the M.A. programme in English Philology and Celtic Studies was launched due to the expressed interest in continuing their studies in the field by the students.

The Celtic specialisation itself has undergone some changes over the years in terms of the numbers and types of courses offered. During the period between 2007-13 students had 5 classes of Welsh a week, which equals 300 academic hours of Welsh per academic year. In addition to Welsh, students also learned Irish (120 hours a year), English and other academic subjects such as Welsh/English/Irish literature and various aspects of linguistics. However, due to a high drop-out rate resulting from a heavy class load the programme was changed and starting from the academic year 2013/2014 students have only 2 classes of Welsh a week, which equals 120 hours of Welsh per academic year. At the time of writing, there were 28 undergraduate students and 5 in the postgraduate programme. Currently, Welsh is taught by four Polish new ${ }^{1}$ speakers of Welsh. However, in the past students had classes also with 'native' speakers of the language from various parts of Wales, e.g. Ceredigion, Gwynedd, and various locations in South Wales. Having a number of well-qualified local (i.e. Polish) staff who are engaged in the teaching of Welsh is seen as a consolidation of the field of Celtic Studies in Polish academia, while retaining close links with colleagues in the United Kingdom, Ireland and Brittany.

This paper aims to explore the motivational factors behind the choice of study of one Celtic language by Polish students - Welsh - and how this relates to wider ideologies of language, particularly the concept of utility of learning a lesser used language. We will briefly examine the theoretical field of motivation in language acquisition before applying it to some ethnographic fieldwork conducted among students in Poznań during the academic year 2014-15.

\section{Motivation Theory}

The concept of motivation has been extensively studied in both psychology, educational studies and applied linguistics contexts since the publication of the

We use the term 'new speaker' in the sense employed by the COST Action network on this theme (IS1306: New Speakers in a Multilingual Europe. Challenges and Opportunities) which characterises such a speaker as someone who has acquired or is acquiring a language in addition to their L1, through non-intergenerational means and who then engages with the language meaningfully outside of a classroom setting. The writing of this paper has benefitted from on-going discussions of the concept of the 'new speaker' within the framework of the Action. 
seminal work by Gardner and Lambert (1972) and Gardner (1979) and many subsequent theories of motivation have been proposed (Dörnyei 2001). In their model, Gardner and Lambert (1972) distinguish between integrative motivation and instrumental motivation. Integrative motivation denotes a desire not only to gain proficiency in the target language but also to become a valued member of the target language community. Instrumental motivation means learning a target language for pragmatic gains, e.g. better employment prospects. These two types of motivation should not be understood as a dichotomy but as "positively related, affectively loaded goals that can sustain motivation" (Clement et al. 1994: 420).

Research into motivation conducted in the 1980s has shown that the two types of motivation proposed by Gardner and Lambert are not cross-culturally pervasive (Skehan 1991). Rather, they constitute differing clusters of orientations whose definitions depend on the sociocultural factors in the target language learning environment (Clement et al. 1994: 420). In addition, Dörnyei (1983) observed that in contexts where there is limited or no contact between the learners and the target language community, such as language classrooms, ethnocultural attitudes towards target language communities cannot play an important role. Instead, the affective aspects of motivation are sustained by language learning aptitude of the learner and the values conveyed by the target language. However, Clement et al. (1994) argue that when direct contact with speakers of the target language is limited but indirect contact with the target language culture is considerable, students' self-confidence constitutes a motivational subsystem in learning foreign languages. As will be shown below, however, limited access to target language communities does not necessarily preclude the development of attitudes towards these communities and affective dispositions towards them and their languages.

In their study of motivation and language attitudes of Hungarian students, Dörnyei et al. (2006) distinguish seven components of motivation in foreign language learning:

1. Integrative dimension, which corresponds to Gardner and Lambert's (1972) integrative motivation

2. Instrumental dimension, which corresponds to Gardner and Lambert's (1972) instrumental motivation

3. Attitudes towards the L2 Speakers/Community

4. Milieu, which constitutes the influence of the significant persons in one's environment (e.g. parents, family members and friends) on language learning motivation

5. Linguistic self-confidence, that is one's personal beliefs about their abilities to learn a language 
6. Cultural interest, which is particularly relevant in foreign language learning environments when the direct contact with the target language speakers is limited and, hence, contact-based attitudes towards target language speakers cannot be developed. Indirect contact with the target language community and their culture through films, music, books etc., however, may positively impact on individual's motivation and attitudes

7. Ethnolinguistic vitality, which is based on Giles and Byrne's (1982) 'intergroup model' and refers to "a particular ethnic group's distinctiveness as a collective entity" (Dörnyei et al. 2006: 15) and pertains to minority ethnic groups in multicultural settings, where members of the minority group learn the dominant language. Ethnolinguistic vitality is defined by status, demographic and institutional support factors.

The study discussed by Dörnyei et al. (2006) and the study discussed in this paper are similar in that both were conducted in monocultural settings. The setting for the current study can certainly be seen as overwhelmingly monocultural and monolingual as well. In Poland, Polish is the official language, and the state also recognizes Kashubian ${ }^{2}$ as the 'regional language'. A number of other languages, designated 'minority', such as Lemko, German, Belarusian, Ukrainian and Romani, are spoken across various localities, yet only around $6 \%$ of the Poland's population declares any ethnic and linguistic affiliation other than Polish. None of the participants in the study had a national minority background. Although PolishEnglish and Polish-Scottish linguistic and cultural contacts have been wellestablished for a few centuries, a similar tradition of Welsh-Polish contact or migration is much less evident. Wales is 'invisible' for the majority of Poles, and its status as a separate country with its own distinct language and culture and is often synonymous with 'England' and 'Great Britain' (cf. Gramich 1997: 108, for comparison with other countries in Europe). Hence, cultural interest, linguistic self-confidence, integrative dimension and attitudes towards the L2 community play a decisive role in the motivation behind Polish students learning Welsh as a foreign language in Poland. As far as foreign language learning ${ }^{3}$ is concerned, 44

2 Kashubian is spoken by about 106,000 speakers the Pomeranian Voivodeship in northern Poland (Olbracht-Prondzyński and Wicherkiewicz 2011).

Foreign language learning refers to learning a target language outside of the target language community, predominantly in a formal environment of a language classroom. In contrast, second language learning means learning a target language in both formal and informal ways with direct access to target language community. 
per cent of the Polish population is monolingual, 38 per cent declare knowledge of one foreign language, 15 per cent declare knowledge of two foreign languages and only 3 per cent claim to speak three languages or more. The most popular foreign language is English, followed by Russian, German, French, Italian and Spanish (TNS Polska 2015: 5) ${ }^{4}$.

\section{Methodology}

The discussion below presents a selection of results of the study into the motivation of Polish university students in learning Welsh as a foreign language. Although there are a number of studies in motivation for learning minority languages within minority speaking communities (e.g. PritchardNewcombe 2007, Jones 1991, Wright and McGrory 2005, McLeod et al. 2010) little research exists on learners studying minority languages as foreign languages per se and with limited access to speakers and the associated culture of the target language.

The study was conducted in May 2015 and took the form of focus groups interviews with 16 undergraduate and 5 postgraduate students of Celtic Studies at the Faculty of English, Adam Mickiewicz University, Poznan. These focus group interviews were conducted in Polish. As O'Rourke notes, "a focus group can be described as a socialized conversation ... it elicits more natural and spontaneous responses in a group setting" (O’Rourke 2011: 332). Furthermore, a focus group takes the pressure off individuals. So when a participant does venture an opinion, it is more likely to be a statement that the participant feels a need to voice, rather than just speaking for the sake of speaking. However, this does give licence for some participants to take a back seat in the proceedings, as it were, and to let others speak for them. The last point highlights the need for alternative data collection methods for an on-going study of the issues presented in the present article. The interviews were 45 minutes in length on average. The students represented different levels of experience learning a minority language in a foreign language context and of proficiency in Welsh, ranging from basic communicative skills to advanced levels.

All research participants were proficient in English, since advanced skills in that language are entry requirements for all students of English philology at the university, due to all courses being conducted through the medium of English. The Polish educational system require all children to learn one foreign language

4 These statistics reflect the findings of Główny Urząd Statystyczny (Central Statistical Office) in 2011 (stat.gov.pl/cps/rde/xbcr/gus/wz_jakosc zycia I spojnosc spoleczna.pdf) 
from the age of 6 and two foreign languages from the age of 13. The obligatory teaching of a foreign language at pre-school level is going to be introduced in 2016; however, many pre-schools offer it already. Taking these two factors into account, the linguistic self-confidence of the participants in that study was assumed to be high and the need to measure it deemed unnecessary on this occasion.

\section{Welsh speakers in Poland - themes}

Many themes, too numerous to be cited here in their entirety, emerged from the semi-structured interviews conducted with students of Welsh at Adam Mickiewicz University in Poznań, Poland. We have therefore condensed the student responses into 7 major themes, which represent the discourses present among the students, presenting a flavour or a vignette of their interactions with the Welsh language, as learners and/or as new speakers of Welsh outside of Wales. These themes are:

1. Impressions of the language before beginning to study

2. Cultural connections

3. Dealing with general impressions in Polish society of Wales and the Welsh language

4. Language acquisition

5. Discomfort in the learning process

6. Justifying their educational choices

7. Own use of Welsh

Throughout these themes, we have been careful to identify instances of how new speakers of Welsh from Poland describe and index their motivational reasons for learning and how this is important for future research and policy directions in Wales and in Poland.

\subsection{Impressions of the language before beginning to study}

Why take up the study of Welsh in Poland? Many of the students talked in terms of doing something original and interesting, if not exotic:

była szansa nauczenia się czegoś nowego a nie powtarzanie starych informacji (it was a chance to learn something new, not just revising old stuff/information) [F2S1]

coś oryginalnego 
(something original) [F2S3]

interesuję się językami oryginalnymi, ciekawymi

(I'm interested in original, interesting languages) [F2S2]

and in one case, Welsh proved to be just a little less exotic than South African studies ${ }^{5}$ :

że RPA jednak jest zbyt odległa i egzotyczna

(that the South African specialization is a bit too distant and exotic) [F1S3]

Thus, we can clearly discern a tendency to view Welsh, a language from the western edge of the European Union, as something which is view as exotic, or unusual in Poland, located as it is at the other end of the European Union. In a small way, then, the study of Welsh in Poland can be viewed as a step toward greater European integration, with the appreciation of a small, minority language in another EU state. This interest is uni-directional, however; whereas some interest in Polish matters is to be found in Wales, including among Welsh speakers (evening class in Polish in Wales, for example), there appears to be little awareness of the rich array of minority languages which are to be found in Poland, and even less any academic engagement with them.

\subsection{Cultural connections}

For one participant, it was more important to connect to Welsh culture, and the only way to do this, she felt, was through the language:
Jeśli chodzi o motywację to była głównie kulturowa. Nie językowa. Język jest dla mnie tylko medium, żeby dowiedzieć się więcej o kulturze ... jeśli chce się zanurzyć w tą kulturę Walii, trzeba mimo wszystko znać język.
(When it comes to motivation it was mainly cultural, not linguistic. For me language is only a medium to learn more about culture.... if you want to immerse yourself in Welsh culture, you have to speak the language). [F4S1]

Learning Welsh as a foreign language, then, stems from cultural interest, a desire to become (more) familiar with a culture perhaps not encountered before, rather than instrumental motivation. Despite the fact that Wales and her culture is rarely represented in English as a foreign language classes and the awareness of its indigenous cultural and linguistic heritage is low among the general public in Poland, young people gain some knowledge of Celticity and the Celtic

5 All students of English Philology at AMU have to choose a specialization on commencing the studies. Apart from Celtic Studies, teaching, academic and South African specializations are offered at the undergraduate level. 
languages from popular culture. Computer games and fantasy books, in particular by J.R.R Tolkien and Andrzej Sapkowski ${ }^{6}$, are among the most often mentioned origins of interest in Celtic matters among Polish students.

\subsection{Polish impressions of Wales and the Welsh language}

One major factor students have to deal with is the impressions people in Poland have about Wales and the Welsh language. In fact, sometimes not even knowing that Wales existed as a separate entity to England, and that Wales has its own indigenous language, was a big stumbling block in explaining their educational choices to their peers and parents:

Chyba wśród 90\% polskich uczniów jest kompletna nieświadomość, że języki celtyckie to jest kompletnie odrębna grupa języków i w żaden sposób nie przypominają języka angielskiego.

(I think about $90 \%$ of Polish students are completely unaware that the Celtic languages is a completely different group of languages and they don't resemble English in any way). [F1S4]

O językach walijskim i irlandzkim w ogóle mało wiadomo, ludzie myślą, że to są dialekty angielskiego.

(Little is known about Welsh and Irish, people think they are dialects of English). [F2S4]

Jedyna rzecz, jakiej dowiedziałam się ucząc się angielskiego w liceum było to, że Walia jest strasznie biedna, że tam nikt nie mieszka i że wszyscy młodzi wyjeżdżają z Walii jak szybko się da. Uważam, że to jest... no tak się pokazuje Walię w podręcznikach.

(The only thing I learned in secondary school in English classes was that Wales is very poor, that nobody lives there and everyone leaves Wales as soon as possible.

I think it's... well that's how Wales in presented in the course books). [F4S1]

This is a common perception among people outside the United Kingdom - that 'England' is synonymous with the other constituent countries of the United Kingdom and that Celtic languages, such as Welsh or Gaelic are not languages in their own right, but dialects of English. The presence of Celtic language programmes in Europe is, therefore, a timely reminder that the United Kingdom is not a monolingual state, and that a variety of smaller, minority languages enjoy different degrees of official recognition at regional and state levels. This is not to mention, of course, the plethora of languages spoken by other migrant and more longer established communities in all parts of Britain.

6 Andrzej Sapkowski (1948 - ) is a Polish author of fantasy books, famous in particular for his Witcher (Wiedźmin) series. 


\subsection{Language acquisition}

Becoming a new speaker of Welsh, outside of Wales, represents much hard work for all students involved in the programmes of study at the university. This is of course true for all language students everywhere, but the students mentioned lack of access to 'authentic' materials, and to speakers with whom to practise. The department occasionally has visitors from Wales who have been happy to speak Welsh to the students, and there are plans to twin with Bangor University through Skype sessions and, therefore, use the language for informal conversations with peers from Wales. Students mentioned that, as far as the learning process entails, there are particular highs and lows associated with learning Welsh which they have not encountered when learning other languages:

Na pewno na początku bardzo nas bawił ten język, bo hoffi-coffi, to się wszystko rymuje, $b w r w-c w r w$, sobie własne frazeologizmy tworzyliśmy, ale chyba jednak szybko pojechaliśmy z tym językiem, ze względu na te 5 godzin w tygodniu, ale też ze względu na przystępność tego języka, był łatwy.

(For sure, in the beginning the language was very entertaining because hofficoffi, everything rhymes, bwrw-cwrw, we created our own phrases, but we got better in it [Welsh] quite quickly because of the 5 hours a week, but also because the language was accessible, easy). [F1S1]

Na początku miałam problem z tym, że nie wiedziałam, gdzie się mutuje, to była dla mnie czarna magia

(My problem in the beginning was that I didn't know when I should mutate, it was black magic). [F3S1]

Some aspects of learning Welsh, however, did not differ vastly from their experiences of learning other foreign languages. In fact, the students said that they found some aspects, such as phonetics and the prosody of Welsh, easier to learn when compared to English, for example, as there exist significant similarities between Welsh and Polish, at least as far as phonetics is concerned.

W sumie gramatyka jak się zastanowi, wgryzie w te struktury nie spotkane wcześniej to jest to logika ... z czasem zaczyna się to samo ucierać.

(Actually when you think about grammar, study the structures you had not known before it is logical ... with time it all becomes obvious.) [F1S4]

Ja myślę, że melodia języka ogólnie jest prosta, bo akcent jest na tą samą sylabę co w polskim, nawet nie trzeba myśleć jak się czyta.

(I think that the melody of the language is very easy because it is accented on the same syllable as Polish, you don't even have to think about it when you read). [F2S5] 
This aspect of Welsh learning merits further research. The majority of learners of Welsh have English as their mother tongue and of course this implies that certain translanguaging features may be evident in their linguistic practices and teaching materials are subsequently adapted to take this into account. However, there is a growing number of Welsh new speakers in Wales who have a language other than English as their first language and this needs to be taken into account when preparing pedagogical materials as the field of Welsh teaching expands and develops over the course of the 21 st century. That there is a small, but not insignificant body of Welsh learners outside of Wales, in Poland, who can provide insight into the learning process of Welsh from a Polish point of view is of course important, given current migration patterns to the United Kingdom in recent decades. With a significant number of Polish speakers who undertake the study of Welsh in Wales, particularly within the schools, refining teaching and learning materials from a Polish perspective would appear to be an important priority for local authorities in Wales at the present time.

\subsection{Discomfort}

One aspect which at least two students mentioned was a certain level of discomfort which crept into the learning process, and which clearly demonstrates particular language ideologies held by the students:

Co jest bardzo przykre, to to, że jest dużo anglicyzmów (...) więc człowiek zawsze ma tą świadomość, że w rozmowie z Walijczykiem może się przełączyć na język angielski.

(What's quite sad is that there are a lot of borrowings from English (...) so one is always aware that when chatting with a Welsh person you can switch to English). [F4S1]

Człowiek się czasem zastanawia nad zasadnością uczenia się tego bo czasem się słyszy więcej angielskiego... albo jest tak zdeformowany, że aż trudno patrzeć. Ja sobie wyobrażam człowieka mówiącego łamanym polskim do tego stopnia, że aż ciężko go zrozumieć. To co muszą czuć osoby, które biegle mówią w tym języku. (You sometimes start to think about the validity of learning it because sometimes you hear more English ... or it's so deformed that it's sad to hear it/look at it. [In such situations] I imagine a person speaking Polish broken to such an extent that it's difficult to understand. What must people who speak it fluently then feel). [F4S2]

The Polish experience of language learning, whereby the ideology of the standard is all pervasive, seems to influence attitudes toward the Welsh language in its current state. Welsh speakers, either traditional or new in their acquisition of the 
language, can use translanguaging features whereby, not unnaturally or unexpectedly, the influence of English is detectable. This can sit uneasily with Polish speakers who are not used to such linguistic practices in their own language environments and where linguistic variation is not regarded as appropriate for most contexts. Understanding this difference in approach to language ideologies is a key component in a non-UK setting and needs to be emphasized and made explicit in any Welsh language teaching programme in Europe.

\subsection{Justifying their learning of Welsh}

The reactions of others (i.e. the milieu dimension of motivation) to the students' choice of subject at university level can of course have a major effect on student motivation, both positive and negative. This is particularly the case when students come into contact with people from the United Kingdom, both Welshand non-Welsh-speaking and can put their motivations and reasons for learning Welsh very much in the spotlight, in a way that they do not experience back in Poland. This is not to suggest that their motivations are not sometimes questioned by people in Poland itself, but the underlying questions can arise from very different concerns. For example, below we quote research participants who experienced challenging reactions from people in England and in Poland; the reaction from English people was one of amusement, but from Polish people, there was more concern over the practical application of their studies in the Welsh language.

No właśnie z takim podejściem spotkałam się jak znajomym Anglikom mówiłam, to dla nich był wielki śmiech.

(That's the attitude I came across when I told my English friends, it was a big laugh for them). [F3S1]

Moja rodzina nie była zadowolona początkowo, ponieważ nie ma zbyt wielu okazji do pracy w kraju, jeżeli są to trzeba wyjechać. Ale z drugiej strony też chodzi o to, że ja jestem takim freakiem i oni wszyscy o tym wiedzą, wiedzą, że ja mam fisia na tym punkcie, to rozumieją teraz.

(My family was not very happy initially, because there are not too many job prospects in the country, if there are you have to emigrate. But on the other hand I'm a bit of a freak and they all know about it, they know I'm crazy about it and now they understand). [F4S1]

Kiedyś A. na przykład opowiadał jak próbował dogadać się w bibliotece w Walii po walijsku i pani bibliotekarka zobaczyła, że jest z Polski to od razu przestawiła się na angielski, bo nie chciała dzielić się swoim językiem.

(Once A. tried to speak Welsh in a library in Wales and the librarian, when she saw that he was from Poland, switched to English straight away because she didn't want to share her language). [F1S1] 
Not all experiences are negative, however, and there were some accounts of how knowing Welsh has proved to be of positive benefit to Polish new speakers of Welsh:

Jak byłem w Caernarfon i spotkaliśmy pana bez koszulki $\mathrm{z}$ dużym psem i pięciolitrową butelką cydru to jak się dowiedział, że znamy walijski to nie napuścił na nas psa. A tak poważnie to pozytywne.

(When I was in Caernarfon we met a guy without his T-shirt on and a big dog and 5 litre bottle of cider and when he learned that we speak Welsh he didn't let the dog attack us. But seriously, all positive). [F1S1]

Nie wspominając o Ewie G., która jest teraz pielęgniarką w Cardiff i to, że znała walijski pozwoliło jej znaleźć tańsze mieszkanie.

(Not to mention E.G. who is now a care assistant in Cardiff and because she knows Welsh she could find a cheaper flat). [F1S1]

Finally, in this section, as a minority language, and as one which is competing for students' attention the world over with the global language that is English, at least one student saw very positive attributes to learning and using a minority language, such as Welsh, precisely because it is a minority language, and acts as a kind of antidote to the negative aspects of globalisation:

Języki mniejszościowe wydają mi się o tyle ciekawsze od języków niemniejszościowych, że ich ludność może ma troszeczkę bardziej skomplikowaną psychikę ze względu na wieki życia pod butem lub protekcją silniejszego państwa. Więc po prostu sami ludzie wydają mi się ciekawsi, bardziej empatyczni, bardziej gościnni, ze względu na to, że byli poturbowani przez historię.

(Minority languages seem more interesting to me than non-minority languages because their speakers have has a slightly more complicated psyche because of the centuries lives under the oppression or rule of a stronger country. So the people themselves seem more interesting, more emphatic, more hospitable, because of the fact that they've been mauled by history). [F1S1]

\subsection{Use of Welsh}

The way Polish new speakers of Welsh use the language is of course a paper in itself and space permits us to mention only a couple of memorable citations which seem to characterise their linguistic practices. Being so far from Wales, as has already been noted, is a problem in regularly using the language and, thus, one student points out that his usage reflects this:

Nie mam trudności (w rozmowach ze znajomymi z Walii), ponieważ jest to komunikacja pisemna, więc nawet jeśli są te apostrofy to jestem w stanie się 
domyślić co to jest.

(I don't have any difficulties (when speaking with friends from Wales), because it's written communication, so even when there are a lot of apostrophes I can guess what it is). [F1S1]

This comment also points to the importance of modern media and social networking sites in learning and maintaining minority languages. For the use of Welsh by young bilinguals in Wales on social networking sites see Cunliffe, Morris and Prys (2013) and Jones, Cunliffe and Honeycutt (2013).

An interesting use of the language was mentioned by another student for a very specific purpose:

Ewentualnie używamy walijskiego jako kodu przy osobach, które tego języka nie znają.

(If we use Welsh at all, it's as a code among people who don't speak it). [F1S4]

Thus, even though the opportunities for using Welsh among Polish new speakers of the language appears to be very restricted, there are opportunities for Welsh to be used beyond the classroom and for real communicative purposes. Vital for this use are social media and other outlets on the Internet, which can reinforce the impression that Welsh, like many other minority languages, is moving away from being a community language in certain localities in Wales, to a more networked language, the use of which is not so bounded by time and (physical) space. Whereas we recognize that having particularly localities in Wales as focus points for students to come and be able to use Welsh with others in a community setting is a very important motivation factor in their acquisition of the language, perhaps just as important is the realization that Welsh speakers and the use of Welsh can equally be accessed via modern media and through virtual networks. This is sometimes a much easier option for students who have limited funds and time to be able to travel to Welsh-speaking Wales, and is an aspect which merits further research.

\section{Conclusions}

This very brief overview demonstrates a relatively long history of interest in Celtic studies in Poland, and which over the years has produced a number of 'new' speakers of Welsh outside of Wales, with their linguistic practices very much hampered by relative isolation from other Welsh speakers and from access to materials which would enhance their linguistic practices. Despite limited contact with native Welsh speakers and some negative attitudes towards choosing to learn a foreign minority language, there are also distinct 
opportunities for multilingual Polish students to learn Welsh (linguistically but also culturally). Also, an interesting point to note is that acquiring Welsh is an extension to an already proficient linguistic and cultural knowledge of English. Welsh may thus offer an additional sense of 'otherness' but also an extra resource to students' cultural awareness of the UK, as well adding to their linguistic repertoires.

Many individuals from Wales have contributed significantly to Polish interest in the Welsh language over the years, either through the willingness to come and actively engage in language acquisition with Polish learners of Welsh, or through supporting various initiatives, donations of books, etc. Despite this commitment from individuals from Welsh-speaking Wales, new speakers of Welsh in Poland overwhelmingly have to be highly intrinsically motivated in their language acquisition, as the rewards and benefits of becoming a new speaker of Welsh in Poland are not immediately apparent. This very much ties in with research on motivation which highlights the assimilative aspects of language learning - new speakers of Welsh in Poland are proven successful language learners of other languages, and with Welsh they are extending their linguistic repertoire to include an additional and unusual language. However, with the increased contact between Wales and Poland, and with on-going research being undertaken by a number of scholars both within Poland and in Wales, the presence of Polish speakers in Wales, who most likely represent the third most spoken language in the country, merits very careful attention, particularly in attempts to make all citizens of Wales truly bilingual. By studying Polish attitudes toward Welsh, especially among those Poles about to migrate to Wales, or indeed those Poles who have settled in Wales already, the language policy of the Welsh Assembly can and should be adopted and modified in the light of new and potentially new Welsh speakers of Polish origin. Of particular importance is the need to research further how instrumental and assimilative motivation plays a part in migrant language choices, and how these motivational aspects of linguistic practices can be harnessed for the stabilization of the Welsh language at a time of considerable movement and migration within the EU.

\section{ACKNOWLEDGMENTS}

This research has benefitted from participation in the COST ACTION 'New Speakers in Multilingual Europe: Challenges and Opportunities'. 


\section{REFERENCES}

Bassnett. Susan (ed.). 1997. Studying British cultures: An introduction. London: Routledge.

Bendowska, Marta, Anna Bieńskuńska, Paweł Luty, Karol Sobestjański, Joanna Wójcik. 2011. Jakość życia i spójność społeczna. Warszawa: Główny Urząd Statystyczny

Clement, Richard, Zoltán Dörnyei and Kimberly A. Noels. 1994. "Motivation, self-confidence and group cohesion in the foreign language classroom", Language learning 44(3): 417-448.

Cunliffe, Daniel, Delyth Morris and Cynog Prys. 2013. "Young bilinguals' language behaviour in social networking sites: The use of Welsh on Facebook", Journal of ComputerMediated Communication 18: 339-361.

Dörnyei, Zoltán. 2001. Teaching and researching motivation. Harlow: Pearson Education.

Dörnyei, Zoltán, Kata Csizér and Nóra Németh. 2006. Motivation, language attitudes and globalisation: A Hungarian perspective. Clevendon: Multilingual Matters, Ltd.

Gardner, R.C. and W.E. Lambert. 1972. Attitudes and motivation in second language learning. Rowley, MA: Newbury House.

Gardner, RC. 1979. "Social psychological aspects of second language acquisition", in: H. Giles, and R. St. Clair (eds.), 193-220.

H. Giles, and R. St. Clair (eds.). 1979. Language and social psychology. Oxford: Blackwell.

Giles, H. and J.L. Byrne. 1982. "The intergroup model of second language acquisition", Journal of Multilingual and Multicultural Development 3: 17-40.

Gramich, Katie. 1997. "Cymru or Wales? Explorations in a divided sensibility", in: Susan Bassnett (ed.), 97-112.

Jones, Christine. 1991. "The Ulpan in Wales: A study in motivation”, Journal of Multilingual and Multicultural Development 12(3), 183-193.

Jones, Rhys James, Daniel Cunliffe and Zoe R. Honeycutt. 2013. "Twitter and the Welsh language", Journal of Multilingual and Multicultural Development 34(7): 653-671.

MacMathúna Séamus and Maxim Fomin (eds.). 2006. Parallels between Celtic and Slavic: Proceedings of the First International Colloquium of Societas Celto-Slavica held at the University of Ulster, Coleraine 19-21 June 2005. [Northern Ireland]: Stationery Office.

McLeod, W., A. MacCaluim and I. Pollock. 2010. Adult Gaelic learning in Scotland: Opportunities, motivations and challenges. Inverness: Bòrd na Gàidhlig.

Migration Observatory http://migrationobservatory.ox.ac.uk/press-releases/changes-migrantpopulation-wales-2001-2011 (accessed 6 January 2016).

Olbracht-Prondzyński, Cezary and Tomasz Wicherkiewicz (eds.). 2011. The Kashubs: Past and present. Oxford, Bern, Berlin, Bruxelles, Frankfurt am Main, New York, Wien: Peter Lang.

Pritchard-Newcombe, Lynda. 2007. Social context and fluency in L2 learners: The case of Wales. Clevendon: Multilingual Matters.

Skehan, Peter. 1991. "Individual differences in second-language learning", Studies in Second Language Acquisition 13: 275-98.

Stalmaszczyk, Piotr. 2006. "Celtic studies in Poland: Recent themes and developments", in: Séamus MacMathúna and Maxim Fomin (eds.), 43-62.

TNS Polska. 2015. Znajomość języków obcych. http://www.tnsglobal.pl/wp-content/blogs.dir/9/files/2015/06/K.041_Znajomosc_jezykow_obcych_O05a-15.pdf (accessed 6 January 2016).

Wright, Margaret and Orla McGrory. 2005. "Motivation and the adult Irish language learner", 
Educational Research 47(2): 191-204. 